\title{
Tourism Development in Ebonyi State: Insight into the Challenges Confronting the Ministry of Culture and Tourism
}

\author{
Obinna Emeafor ${ }^{*}$ \\ Department of Archaeology and Tourism, University of Nigeria, Nsukka
}

\begin{abstract}
Ebonyi State Ministry of Culture and Tourism was established in June 2000 to serve as a catalyst for the development of diverse cultural and tourism resources in the state. However, it is worrisome that eighteen years after, not much headway has been made in the development of tourism resources. Some of the implications are that tourism resources have not been tapped for state and rural development, and many of the resources are under threat due to lack of management. Thus, the paper attempted to dissect the obstacles which preclude Ebonyi State Ministry of Culture and Tourism from discharging its cardinal function of tourism development. The key objective of the study was to ascertain the challenges that confront Ebonyi State Ministry of Culture and Tourism. The research adopted the qualitative posture to inquiry, and in-depth interview as primary data gathering technique. Findings revealed that key challenges of the ministry are: lack of appropriate personnel, poor funding, flippant attitude of government towards tourism development, and absence of tourism committee at the thirteen local government areas of the state. It is hoped that the paper will contribute meaningfully towards repositioning the ministry for greater productivity.
\end{abstract}

Keywords: Tourism Development, Challenges, Ministry of Culture and Tourism, Ebonyi State

DOI: $10.7176 /$ JTHS/41-06

Publication date:May $31^{\text {st }} 2019$

\section{Introduction}

Ebonyi State is endowed with rich array of natural and cultural tourism resources such as Amanchor cave, golden sand beaches of Ozizza, Ndibe and Unwana; Ishiagu earthen pottery, Ngene-Ukwuenu - a centre for religious and cultural tourism in Uburu, Ntezi basket weaving, Abakaliki Greater Rice Husk, Slave Market Route at Ezza, Ukpa Rock Shelter, Uburu and Okposi salt lakes, etc. As a result of the rich tourism resources in the state, Ebonyi State Ministry of Culture and Tourism was created in June 2000 to provide the impetus for rapid development of tourism resources. However, it is worrisome that eighteen years after, not much progress has been made by the ministry in the development of cultural and tourism resources.

Some of the consequences are that tourism resources have not been tapped for the benefit of the state and the rural populace; worst still is that many of the resources are languishing due to lack of management. Consequently, the paper endeavored to examine the challenges which preclude Ebonyi State Ministry of Culture and Tourism from accomplishing its fundamental function of developing tourism resources. Thus, the key objective of the study was to ascertain the challenges that confront Ebonyi State Ministry of Culture and Tourism in relation to tourism development. A subordinate objective was to examine the collaboration between the ministry and tourism committee at the local government level in the development of tourism resources. Two local government areas - Abakaliki and Afikpo North were used to address the second objective. The research was conducted in line with the qualitative posture to inquiry, where in-depth interview was used as the primary data gathering technique. Interviews were conducted with senior staff of Ebonyi State Ministry of Culture and Tourism, as well as its agencies - Ebonyi State Council for Arts and Culture, Ebonyi State Tourism Board and Ebonyi Hotels Afikpo/Abakaliki. Interviews were equally conducted at the headquarters of the two local government areas. Secondary sources of data from books, academic journals and public library were used to bolster primary data.

\section{Literature Review}

Governments of various nations are involved in tourism mainly because of economic reasons such as the capacity of tourism to bring about foreign exchange earnings, employment opportunities and diversification of local economy. Governments are also involved in tourism because they have the ability to provide the basic infrastructure necessary for tourism development. In the opinion of Elliot (1997:2), 
Governments are a fact in tourism and in the modern world. It is only governments which have the power to provide the political stability, security and the legal and financial framework which tourism requires. They provide essential services and basic infrastructure. It is only national governments which can negotiate and make agreements with other governments on issues such as immigration procedures or flying over and landing on national territory.

Governments execute these functions through the Public Sector Management (PSM). In the context of tourism, PSM includes public institutions such as ministries, agencies and boards at the national level down to the various units or departments at the local government level, whose functions affect tourism in direct or indirect manner. However, Public Sector Management must carry out these functions in line with the policies stipulated by government which holds the legitimate authority to wield the ultimate power of a sovereign state. Policies do not exist in isolation; they are highly influenced by institutional arrangements which are highly intertwined with politics. Thus, 'understanding tourism policy and planning processes, outcomes and impacts requires reference to the institutional arrangements for tourism policy' (Hall in Ioannides and Debbage (Eds.) 1998:204). Brooks $(1989: 131)$ argues that institutional arrangements influence 'the process through which the policy agenda is shaped, problems are defined, alternatives are considered, and choices are ultimately made'. In addition, Hall and Jenkins (1995:18), remark that 'understanding tourism public policy demands some understanding of and reference to the institutional arrangements in which tourism policy is made'. Consequently, As Duval (2004:100) has rightfully noted, the investigation of institutional arrangements needs to assess the interaction of several pervasive forces, including:

Legislation and regulations

Policies and guidelines

Administrative structures

Economic and financial arrangements

Political structures and processes

Historical and traditional customs and values

Key participants or actors

Inter-organizational relationships.

As it concerns Nigeria, Okpoko P.U. in Okpoko P.U. (Ed.) (2006:245) believes that Nigeria deserves a pass mark in the provision of the fundamental conditions for the emergence of sustainable tourism. He argues that the cultural policy of 1988 , environmental policy of 1989, the tourism policy of 1990, the Nigerian Tourism Development Corporation Decree of 1992, the Environmental Impact Assessment decree of 1992, and the economic policies of indigenization and export production have all the procedural provisions that can galvanize Nigeria's tourism industry towards sustainable path. However, as pleasing as these may appear, there is a wide discrepancy between policy (theory) and implementation (practice). According to Nsizwazikhona and Nokwanda (2015), governments, in most cases, tend to have numerous and promising policies and plans for sustainable tourism development which, unfortunately, do not yield good results because of deficiencies and shortcomings on execution and implementation. As a ministry in a state under the Federal Republic of Nigeria, Ebonyi State Ministry of Culture and Tourism appears be confronted with the challenges presented by the disharmony between policy and implementation. This challenge and many more were among the issues which the paper attempted to examine.

\section{Findings}

Ebonyi State Ministry of Culture and Tourism was created in June, 2000 by the pioneer governor, Dr Sam Egwu. One of the primary functions of the ministry is to fast-track the development of cultural and tourism resources in the state. The ministry is headed by a commissioner who is assisted by a permanent secretary; these two top positions of the ministry are political appointments. Tourism, finance, administration and public relations departments are managed by head of departments (HODs), while the department of culture and archives is led by a director. To efficiently carry out its duties, the ministry consists of three agencies (parastatals) namely: Ebonyi State Council for Arts and Culture, Ebonyi State Tourism Board and Ebonyi Hotels Afikpo/Abakaliki.

All the informants interviewed within the ministry of culture and tourism, together with the interviewees from the parastatals concurred that funding is among the top constraints of the ministry. This is in line with the finding of Agbebi (2014) in his study titled Exploring Tourism Policy, Planning and Governance in the Transformation 
of Nigeria, where 'poor funding,' with a score of $60 \%$, was ranked as the number one constraint to tourism development. Research results show that Ebonyi State Ministry of Culture and Tourism has budgetary problems which present enormous challenges to effectively executing the development of tourism resources. The ministry's unsuccessful attempts through series of application letters to the state government to release fund for the construction of the road leading to Amanchor Cave, one of the most promising cultural tourism resources in the state, is a case in point. The funding challenge also militates against the smooth operation of the ministry and its agencies. For instance, interview at the state council for arts and culture revealed that subvention is always not enough to maintain the council's two mini buses, one hilux van, eleven guest staff and two watchmen.

Poor attitude of the state government towards culture and tourism was also identified as a challenge to the ministry. Manifestations of the state government's posture on cultural matters can be seen in the non-approval of the construction of a state cultural complex. Some informants expressed the view that a state cultural complex can enhance unity among various clans in the state. As a result of the absence of a state cultural centre, the state council for arts and culture does not have a conducive environment to integrate every aspect of arts in their programme, thus, the council dwells largely on performing arts to the detriment of other aspects of indigenous arts.

Another major challenge is the non-existence of a state cultural/tourism policy document which some interviewees blamed on politicization of state ministerial set-up. Absence of a policy document suggests that culture and tourism are low priority sectors. There appears to be a link between the funding issue raised in the preceding paragraph and the absence of a state culture/tourism policy document. As was argued by an informant, justification for adequate funding would have been enhanced if there were a state policy document.

In addition, lack of appropriate personnel to handle the affairs of the ministry is yet another challenge. Data gathered showed that people are employed in the ministry without considering the relationship between the academic background of applicants and the objectives of the ministry. For example, few years back, those in the teaching field such as holders of National Certificate of Education (NCE) and Teachers' Grade II (TC II) holders were asked to transfer to the ministry. Even at this, it is regrettable that recruited applicants are not re-trained and consequent upon this, such members of staff may find it difficult to make meaningful input towards the progress of the ministry.

Furthermore, data collected from Ebonyi State Tourism Board divulged that registration and grading of hotels have not commenced in the state, because the ministry is yet to produce a legal framework within which it can begin the exercise of hotel registration and classification. Although the ministry has written a memo to the state executive council seeking for such authorization, the ministry is yet to receive a reply to that effect. Interviews conducted at the third arm of Ebonyi State Ministry of Culture and Tourism i.e Ebonyi Hotels, Afikpo, showed that infrastructural decay (such as dilapidating buildings and 'epileptic' power supply) is a key challenge starring the government hotel in the face. There is the urgent need to update the infrastructural setting of Ebonyi Hotel to meet the demands of modern day reality, especially with the increasing number of privately owned hotels. As at the time of this research, the hotel had only 10 bed rooms whereas a hotel should have a minimum of 30 bed rooms according to international standard. Again, the absence of perimeter fencing for the hotel raises security concerns. The implication is that the hotel loses some accommodation patronage as many visitors are not comfortable lodging in hotels without perimeter fencing.

It was found that tourism committee is non-existent in the two local government areas used for the study i.e. Abakaliki and Afikpo North. While it was gathered from the ministry that tourism committees were constituted for some local government areas including Abakaliki L.G.A, a senior officer of Abakaliki Local Government Area, who declined to be quoted because he was not authorized to speak on the matter, refuted the claim, arguing that the local government has never had such committee. The fact is that at the time of the research, there was no tourism committee and therefore, the local government does not have a statutory mechanism for achieving the tourism mandate of local government areas as stipulated by the federal tourism policy. The national tourism policy of 1990 gave local government areas the responsibility of identifying tourism resources within their domain, serving as information centres, preserving and maintaining local museums etc.

With the absence of local government tourism committee, attempt was made to find out if the ministry has other strategies for liaising with local communities on culture and tourism related matters. The result of this attempt shows that the State Council for Arts and Culture, for instance, set up a five-man committee drawn from the cultural zones - Izzi, Ezza, Edda, Ehugbo, Igboessa, Ohaukwu, Okpoto, Ivo and Ohaozara. The five-man committee for arts and crafts helps to create cultural awareness among local people and also identifies local arts and crafts which can be developed. The council has also established four textile centres at Afikpo South Local 
Government Area. However, these achievements are a far cry from what it would have been if tourism committees were available in the local government areas.

\section{Discussion}

From research findings, the key challenges of Ebonyi State Ministry of Culture and Tourism can be summarized as inadequate funding, poor government attitude towards culture/tourism, lack of basic tourism infrastructure, inappropriate workforce and absence of tourism committee at local government level. Poor funding of culture and tourism sector in Ebonyi State, just like Nigeria as a country, has been acknowledged as a main problem of cultural resources management. This, however, does not exist in isolation as it can be argued that the funding constraint may be a reflection of the low priority status of culture and tourism on both state and national scale of preference. As remarked by Okpoko, A.I in his typescript titled Culture and Management in Nigeria, cultural development and promotion are low priority areas. Culture is perceived as a phenomenon that does not have direct relationship to the priority needs of the country such as food, clothing, shelter, health and industrialization. As a result, most policy makers suppose that Nigeria's cultural heritage is only fit for occasional presentation, and thus, far removed from our daily life. Certainly, such perception of culture and tourism inevitably results in poor allocation of fund to the sector. According to a report by Emman Ovuakporie and Johnbosco Agbakwuru in the Vanguard Newspaper of May 4, 2016, the minister of Information, Culture and Tourism, Alhaji Lai Mohammed faulted the budgetary allocation to the culture and tourism ministry in the 2016 budget, describing the allocation to the ministry as 'mere tokenism'. The budgetary inadequacy of culture and tourism sector has earlier been raised by Wale Okediran, a former member of Nigeria's House of Representatives in a paper delivered at the 62nd CORA Arts Stampede at the Nationaal Theatre Lagos on July 1, 2007. He wrote:

During my four year tenure as a member of the House Committee on Culture and Tourism, poor funding was the biggest obstacle to the smooth running of the Culture and Tourism sector. With budgetary allocations of less than $1 \%$ of the annual national budget, the Ministry was at the lowest budgetary rung. Even when the National Assembly appropriated funds, the president constituted another implementation committee under the finance ministry to reduce these appropriated votes. To worsen matters, not all of the reduced votes were released to the ministries and agencies.

Funding problem for culture related activities including cultural tourism development appear to be a global issue. Robinson and Picard, in a Study carried out for the Division of Cultural Policies and Intercultural Dialogue of UNESCO (2006), remarked that:

The whole field of cultural policy is fraught with the problem of finding the finances to deal with the protection, preservation and revitalization of cultural heritage. For many politicians, the field of culture is recognized to be unproductive and a drain on resources. As such, culture as marginal issue, has been one of the first areas to be cut when budgets are tight.

By and large, the failure of Ebonyi State Ministry of Culture and Tourism to have recorded significant successes in the aspect of development of tourism resources due to improper funding has some implications. First is that some cultural and tourism resources are under serious threat, while others are on the verge of extinction. Examples include the Afikpo Slave Route which is disappearing as buildings are being erected within and around the slave route, thus, permanently closing up the slave route which is supposed to serve as a historical monument to teach the present and future generations about the dreaded era of slave trade. The cave of Nkpurukem (Mkpume Ukpa) is also under serious threat because it has not been harnessed for religious and cultural tourism purposes. Personal observation reveals that portions of land surrounding the cave, and to a little extent on the cave have been sold off, thus; development actions by owners of the pieces of land can degrade the cave in direct or indirect manner. The various engravings on the rocks pose another serious threat to the survival of the cave. It was gathered that visitors to the cave, especially students leave signs of their visit to the cave by engraving there nicknames on the rocks. This is done by chipping away parts of the rocks. Chipping of rocks and monoliths by tourists as an unethical behavior has been reported by Fennell (1999:251) in his study of the great Ayers Rock of Central Australia:

While upon Ayers Rock, I witnessed two tourists in their early twenties chip away pieces of this monolith as souvenirs to take home. It led me to wonder what the implications of this behavior would be if all tourists had done the same. It would not take long for such effects to become highly noticeable.

To prevent the tourism assets from further damage and abuse, adequate funding is needed for their 
development which will involve preservation, conservation and reconstruction. Cultural tourism professionals and planners in Ebonyi State can make strong arguments for proper funding of tourism by delineating the benefits that can accrue from tourism activities. Cultural festivals such as the Izzi Cultural Carnival and the Ikeji festival of the Afikpo group, for instance, can draw large crowd into host communities, the crowd who come to witness aspects of tangible and intangible culture of destination areas will no doubt make some spending in form of food, drinks, communication services and inter-community transportation, which will increase economic activities within and around destination communities. As a result, people who attend such cultural festival will constitute an ideal target market. By presenting the justification for proper funding of cultural tourism activities in this manner, decision makers can readily understand and appreciate the very many roles cultural tourism can play in development.

Lack of basic infrastructure for tourism was identified as another serious challenge as in the case of the deplorable road to Amanchor cave, one of the most enthralling tourism attractions in Ebonyi State. Lack of adequate tourism facilities as a main constraint to tourism development has also been identified by Ogonna and Igbojekwe (2013) in their empirical study on Local Government and Responses to Sustainable Tourism Development in Imo State. In the study, they found that lack of adequate facilities to attract and provide for visitors have significantly constrained tourism development. In the existing literature, tourism infrastructure is recognized as a top priority in determining the flow of tourism. Scholars such as Inskeep (1991) and Gunn (1988) have argued that the strength of infrastructure in any given state significantly influences the attractiveness of tourism destinations. Likewise, Okpoko A.I and Okpoko, P.U. (2002:108-109) affirmed that the provision of tourism products and services and their capacity to draw visitors to a particular destination are determined by certain variables top among them being infrastructure. For instance, good road network and quality transportation system will augment tourists' accessibility to various tourism destinations; and proper healthcare system, waste management mechanism and clean environment will assure visitors that their health will not be put in jeopardy while away from home.

As a result of poor infrastructure, especially road network, most developing countries such as Nigeria have been shut out of the benefits expected to accrue from tourism. This was the case in most of the tourism sites used for the study. The narrow and bumpy path to Isi-Nwanze waterfall in Afikpo North Local government, and the locally made bridge constructed with bamboo leading to Okemini Shrine in Abakaliki Local Government Area are used as illustrations. A further illustration from study areas is the Abakaliki Rice Mill Complex where absence of tourism infrastructure such as clinic, toilet facilities, electricity and pipe-borne water present major discouragement to a potential agro-tourism visitor.

Since it makes no sense to develop tourism resources where there is non-availability of basic tourism infrastructure, the question then is: 'How can the development of infrastructure for tourism in study area be achieved?' Much of the solution can be found in the ability of Ebonyi State government to muster the political will to reposition tourism as a veritable tool in the process of development. It is instructive for the government of Ebonyi State to realize that it performs many functions 'as developer and producer, as protector and upholder, as regulator, as arbitrator and distributor, and as organizer' (Davis, Wanna, Warhurst, and Weller, 1993), and 'each of these functions affects various aspects of tourism including development, marketing, policy, promotion, planning and regulation'. Accordingly, government must be proactive and not reactive in the process of cultural and tourism development in Ebonyi State. The development of infrastructure for tourism should be integrated with the larger state development, such that there will be balanced relationships between the various components of a state such as among infrastructure, the economy, ecosystems and the rural communities who are mostly the providers of tourism resources and activities.

Another challenge was the non-existence of tourism committee at Abakaliki and Afikpo Local Government Areas, thus, the local government areas do not have a formal body which can satisfy the mandate given to local government areas as stipulated by the national tourism policy of 1990. This finding echoes that of Ogonna and Igbojekwe (2013) in their study entitled Local Government and Responses to Sustainable Tourism Development in Nigeria. They found that none of the local government areas in Imo State has a tourism committee as provided in the national tourism policy and decree 81 of 1992. The non-existence of tourism committee suggests that identification of cultural and tourism resources, especially those in the remote areas may present stiffer challenges for the ministry of culture and tourism. Thus, creating tourism committees in all the local government areas in Ebonyi State is considered a sin-qua-non to sustainable tourism development. This is true because harnessing and promoting tourism at the grassroots involves adequate partnership between tourism institutions and the local people. This partnership requires facilitation of which tourism committee will be in the best shape to offer. It should be borne in mind that successful tourism planning requires robust support from the local 
government. Again, as custodians and interpreters of the tourism base of destination, tourism committee should serve as a go-between for adequate involvement of community members so that tourism planning and development can come to fruition.

Where available, local government tourism committee is expected to serve as a link between local people who are the custodians of cultural resources and the state ministry of culture and tourism. And it will suffice to argue that achieving pro-poor tourism objectives will be very difficult if not impossible, because without tourism committees, poor local people who are the target of pro-poor tourism will find it increasingly hard to be integrated into tourism planning and development. Without this integration, the tourism system, according to the General Systems Theory will experience various pathologies which will make the development unsustainable. Community participation in tourism development will be enhanced by the existence of tourism committee at the level of local government; this will also enhance the efforts being made by Ebonyi State Ministry of Culture and Tourism in the development of tourism resources in the state.

Although the study centres on an examination of the challenges which confront Ebonyi State Ministry of Culture and Tourism in the discharge of its duties, it will be unfair to round off the paper without hinting at the various achievements of the ministry towards culture and tourism development. The ministry creates cultural and tourism awareness by publishing the outcome of the ministry's research and survey on major cultural resources in Ebonyi State; and also through the production of cultural/tourism promotion jingles transmitted through Unity FM, Ebonyi State. The ministry also attends cultural festivals which are used as platform for sensitizing the populace on the relevance of culture and tourism in the development process. Furthermore, in an effort to stimulate cultural revival and awareness, the culture and tourism ministry collaborated with the state government in establishing cultural centres for some clans such as: Nnodo cultural complex for Izzi clan; Noyo cultural complex for Ikwo people, Ezza- Ekuna cultural centre for Ezza people and Ohaozara cultural centre. However, much ground needs to be covered by the ministry especially in the area of development of tangible aspects of cultural resources which more often than not, are potential tourism destinations.

\section{Conclusion}

It is not that the statutory bodies saddled with the responsibility of culture and tourism development do not know what to do, rather, managers in the tourism public sector are always fettered by policies which provide guidelines on what to do and what not to do. Thus, it is recommended that Ebonyi State Ministry of Culture and Tourism should be given more freedom and flexibility which will allow the institution to take initiatives that will benefit tourism development. Such arrangement allows for the recruitment of expert staff who understand the dynamic, fragmented and competitive nature of the industry, and the need to be supple and swift in response to these. The Nigerian institute for hospitality and tourism which is responsible for training of tourism professionals can be very useful in providing personnel needed to reposition tourism, so that the sector can contribute meaningfully to socio-cultural and economic development of Ebonyi State and Nigeria in general.

Another recommendation concerns the urgent need to establish tourism committee in the thirteen local government areas in Ebonyi State. Elliot (1997:50) submits that tourism management at the local government level is vital, as this is normally where the impact of tourism is directly felt most acutely. Again, statistics is very important in developing Tourism Satellite Account (TSA) or a reliable database for tourism. In this regard, also, local government tourism committee has important functions to perform in generating the database since most of the tourism resources are located in rural areas.

Conclusively, it will suffice to state that 'government is the principal actor in the political process of tourism development' (Bramwell 2011 in Vujko and Gajic 2014). This suggests that the institutional arrangement for tourism policy is very much interlaced with politics, thus, government of Ebonyi State is expected to summon the political courage to develop the exquisite tourism resources in the state for the benefit of society.

\section{References}

Agbebi, P.A. (2014). Exploring Tourism Policy, Planning and Governance in the Transformation of Nigeria Economy. In Journal of Tourism and Hospitality 3:129. Doi 10.4172/2167

Brooks, S. (1993) Public Policy in Canada, Toronto: McClelland and Stewart.

Davis, G., Wanna, J., Warhurst, J. and Weller, P. (1993). Public Policy in Australia. St Leonards: Allen and Unwin. 
Duval, D.T. (2004). Tourism in the Caribbean: Trends, Development, Prospects. New York: Routledge.

Elliot, J. (1997). Tourism: Politics and Public Sector Management. London: Routledge.

Fennell, D.A. (1999). Ecotourism: An Introduction. London: Routledge.

Gunn, C.A. (1994, 3rd edn.). Tourism Planning, Washington, DC: Taylor \& Francis.

Hall, M.C. The Institutional Setting - Tourism and the State.In Ioannides, D. and Debbage, K.G. (Eds. 1998). The Economic Geography of the Tourism Industry: A Supply-Side Analysis. London: Routledge.

Hall, C.M. and Jenkins, J. (1995) Tourism and Public Policy, London: Routledge.

Inskeep, E. (1991). Tourism Planning: An Integrated and Sustainable Development, New York: Van Nostrand Reinhold.

Nsizwazikhona, S.C. and Nokwanda, X. (2015). The Role of Local Government to Facilitate and Spearhead Sustainable Tourism Development. In Problems and Perspectives in Management(open-acess), 13(4).

Ogonna, C.O. and Igbojekwe, P.A. Local Government and Responses to Sustainable Tourism Development in Nigeria: A Study of Local Government Authorities in Imo State. Retrieved February 22, 2018 from http://www.ijbts-journal.com/images/main_1366796758/0053-Ognonna.pdf

Okediran, W. Our Art, Our Democracy: The Review of Nigeria's Cultural Sector. Retrieved February 13, 2016 from https://www.africanwriter.com/our-art-our-democracy

Okpoko, A.I - Typescript on Culture and Management in Nigeria.

Okpoko A.I and Okpoko, P.U. (2002). Tourism in Nigeria. Nsukka:

Afro-Orbis Publications Limited.

Okpoko, P.U. Sustainable Tourism as a Development Option for Nigeria. In Okpoko, P.U. (Ed.) (2006). Issues in Tourism Planning and Development. Nsukka: Afro Orbis Publications Ltd.

Ovuakporie, E. and Agbakwuru, J. 2016 Budget: Buhari's Allocation to Tourism, Mere Tokenism - Lai Mohammed. Retrieved February 20, 2018 from https:/www.vanguardngr.com/2016/05/2016-budget-

Robinson, M. and Picard, D. Tourism, Culture and Sustainable Development. Being a Study carried out for the Division of Cultural Policies and Intercultural Dialogue of UNESCO (2006).

Vujko, A. and Gajic, T. The Government Policy Impact on Economic Development of Tourism. In Economics of Agriculture, 3/2014, UDC: 35.073.1:338.48. 